\title{
When Whales Became Mammals: The Scientific Journey of Cetaceans From Fish to Mammals in the History of Science
}

\author{
Aldemaro Romero \\ Additional information is available at the end of the chapter
}

http://dx.doi.org/10.5772/50811

\section{Introduction}

Cetacea (whales and dolphins) is a natural group that has for centuries generated a great deal of misunderstanding and controversy regarding its proper place in natural classification. As late as 1945 Simpson wrote that "Because of their perfected adaptation to a completely aquatic life, with all its attendant conditions of respiration, circulation, dentition, locomotion, etc., the cetaceans are on the whole the most peculiar and aberrant of mammals."

Although both molecular and paleontological data have provided a much better understanding of the placement of this group among mammals, there is no question that despite being studied and dissected by dozens of naturalists since Aristotle, these animals were always misclassified. This group provides an interesting case study for intellectual inertia in the history of science. In other words, why did so many scientists misplace this group in the natural classification despite the fact that they themselves were gathering critical information that showed the close relationship these animals had to what we know today as mammals?

The aim of this chapter is to explore this question. To that end I will (1) survey the naturalists who studied cetaceans providing clues of their true nature, (2) describe the intellectual environment in which their conclusions were made, and (3) discuss the factors behind this intellectual inertia.

For the purpose of this chapter I have only taken into consideration works that had some scientific basis and/or that in some ways influenced the process of placing cetaceans as mammals. Authors are enumerated based on the date of the major publication they produced on cetaceans. For synonyms in names of marine mammals through time see Artedi (1738) and Linnaeus (1758). 


\section{Ancient times}

\subsection{Aristotle}

Aristotle ${ }^{1}$ was the son of Nicomachus, the personal physician of King Amyntas of Macedon and Phaestis, a wealthy woman ${ }^{2}$. Nicomachus may have been involved in dissections (Ellwood 1938, p. 36), a key tool in Aristotle's biological studies, particularly on marine mammals. Aristotle lost both his parents when he was about 10 and from then on he was raised of his uncle and/or guardian Proxenus, also a physician (Moseley 2010, p. 6). Early Greek physicians known as asclepiads usually taught their children reading, writing, and anatomy (Moseley 2010, p. 10).

In 367 BCE Aristotle moved to Athens to study at Plato's Academy, and later travelled throughout Asia Minor and studied living organisms while at the island of Lesbos (344-342 BCE) where he collected a lot of information about marine mammals. He later created his own philosophical school, the Lyceum, in Athens where most of his written work was produced between 335 and 323 BCE.

Aristotle is the first natural historian from whom we have any extensive work. One of his surviving opuses is Historia Animalium (inquiry about animals) ${ }^{3}$. There he classified animals as follows (beginning from the top): "blooded" animals (referring to those with red blood, vertebrates) with humans at the top, viviparous quadrupeds (what we would call terrestrial mammals), oviparous quadrupeds (legged reptiles and amphibians), birds, cetaceans, fishes, and then "bloodless" animals (invertebrates). He named each one of these groups a "genus."

Humans

Viviparous quadrupeds (terrestrial mammals)

Oviparous quadrupeds (reptiles and amphibians)

Birds

Cetaceans

Fish

Malacia (squids and octopuses)

Malacostraca (crustaceans)

Ostracoderma (bivalve mollusks)

Entoma (insects, spiders, etc.)

Zoophyta (jellyfishes, sponges, etc.)

Higher plants

Lower plants

Based on the "kinds" of animals and the varieties he described we can distinguish somewhere between 550 and 600 species. Most of them he had observed directly and even

\footnotetext{
${ }^{1} b$. Stagira, Chalcidice, Macedonia, today's Greece, 384 BCE; $d$. Chalcis, Euboea, Ancient Greece, today's Greece 322 BCE

${ }^{2}$ Biographical information on Aristotle is largely based on Barnes (1995).

${ }^{3}$ We used the text available at http://classics.mit.edu/Aristotle/history_anim.html
} 
dissected but others were based on tales and he warned about the accuracy of those descriptions. For example, although he mentioned information in numerous occasions provided to him by fishers, many times (but not always) he debunks some of the fallacies he heard based on his own observations, particularly when it came to reproduction.

Of what we would consider today as mammals (including cetaceans) he described about 80 and about 130 species of fishes, which, again, underlines the extensive work, he did on marine creatures, mostly while living at Lesbos. Under the genus "Cetacea" he included at least three species: (1) "dolphins" probably a combination of striped dolphin (Stenella coeruleoalba, the most frequent species in the Mediterranean), the common dolphin (Delphinus delphis), and the bottlenose dolphin (Tursiops truncatus); (2) the harbor porpoise (Phocoena phocoena) which he described as "similar to dolphins but smaller and found in the Black Sea" ("Euxine") (HA 566b9)4; and, (3) the fin whales (Balaenoptera physalus) another common species in the Mediterranean at that time.

The motives behind Aristotle classification system, particularly animals, were not biological in nature but rather philosophical. For him these creatures were evidence for rational order in the universe. This approach meant that species were rigid elements of the world and, thus, he never contemplated mutability or anything close to evolution, despite the fact that earlier Greek philosophers such as Anaximander envisioned the mutability of species. Furthermore, Aristotle's motive for conducting this categorization was done in such a way that we can then identify the causes that explain why animals are organized the way they are. His investigation into those causes is carried out in other surviving biological works (e.g., Parts of Animals). When describing species he adhered to his teleological doctrine of purposiveness in nature.

Aristotle was able to distinguish between homology and analogy, recognizing cetaceans as a natural group with many similarities with other mammals ("viviparous quadrupeds"). He considered cetaceans as "blooded" animals, adding, "viviparous such as man, and the horse, and all those animals that have hair; and of the aquatic animals, the whale kind as the dolphin and cartilaginous fishes" (HA 489a34-489b3). He also wrote: "all creatures that have a blow-hole respire and inspire, for they are provided with lungs. The dolphin has been seen asleep with its nose above water as he snores (HA 566b14). All animals have breasts that are internally or externally viviparous, as for instance all animals that have hair, as man and the horse; and the cetaceans, as the dolphin, porpoise and the whale -for these animals have breasts and are supplied with milk" (HA 521b21-25). Among the species he described were dolphins, orcas, and baleen whales, noting that "the [whale] has no teeth but does have hair that resemble hog bristle" (HA 519b9-15). Thus, he was the first to separate whales and dolphins from fish.

However, Aristotle placed whales and dolphins below reptiles and amphibians, because their lack of legs, despite his physiological and behavioral observations that they were related more closely to "viviparous quadrupeds" than to fish.

${ }^{4}$ These citations for Historia Animalium follow the Bekker' pagination. 
Aristotle followed his teacher Plato in classifying animals by progressively dividing them based on shared characters. This is an embryonic form of today's classification more fully developed by Linnaeus. The reason he ordered the different "genera" the way he did was because he considered "vital heat" (characterized by method of reproduction, respiration, state at birth, etc.) as an index of superiority placing humans at the very top. Men were superior to women because they had more "vital heat." On this he followed Hippocrates's ideas, since the Greek physician thought there was an association between temperature and soul.

Yet he was not fully satisfied by this approach given that a number of "genera" had characters that were shared across groups, particularly when compared with their habitats. For example, both fishes and cetaceans had fins, but they differ markedly on other characters such as reproduction (oviparous vs. viviparous) or organs (gills vs. lungs, respectively).

Many of Aristotle's observations about cetaceans remain accurate. In terms of internal anatomy he mentioned that they have internal reproductive organs (HA 500a33-500b6), that dolphins, porpoises, and whales copulate and are viviparous, giving birth to between one and two offsprings having two breasts located near the genital openings that produce milk (HA 504b21), that dolphins reach full size at the age of 10 and their period of gestation is 10 months, show parental care, some may live up to 30 years and this is known because fishers can individually identify them by marks on their bodies (HA 566b24), and that dolphins have bones (HA 516b11).

Regarding behavior and sensory organs he said that dolphins have a sense of smell but he could not find the organ ( $H A$ 533b1), that dolphins can hear despite the lack of ears ( $H A$ 533b10-14), produce sounds when outside the water (HA 536a1), that dolphins and whales sleep with their blowhole above the surface of the water (HA 537a34), are carnivorous (HA 591b9-15), and swim fast (HA 591b29).

He held that cetaceans are not fishes because they have hair, lungs (HA 489a34), lack gills, suckle their young by means of mammae, they are viviparous (HA 489b4), and that their bones are analogous to the mammals, not fishes. Still they he calls them "fishes" (HA 566b2-5).

These basic Aristotelian biological descriptions persisted for good and for bad until Charles Darwin's evolutionary work. On one hand his descriptions were so accurate that Darwin admired Aristotle, to the point that he said privately that the intellectual heroes of his own time "were mere schoolboys compared to old Aristotle." ${ }^{5}$ Yet the fact that Aristotle saw the natural world as fixed in time with no room for evolution and that he kept calling cetaceans "fishes," would delay intellectual progress for many centuries when it came to the classification of these animals.

${ }^{5}$ Darwin Correspondence Database, http://www.darwinproject.ac.uk/entry-11875 accessed on 25 Feb 2012. 
Aristotle's influence on naturalists' classification of life would extend until Darwin's times when evolutionary views replaced the fixity of species as elements in nature.

\subsection{Pliny the elder}

Pliny the Elder ${ }^{6}$ was the son of an equestrian (the lower of the two aristocratic classes in Rome) and was educated in Rome. After serving in the military he became a lawyer and then a government bureaucrat. In these positions he travelled not only throughout what is Italy today but also what it would later became Germany, France and Spain as well as North Africa (Reynolds 1986).

He wrote a 37-volume Naturalis Historia ${ }^{7}$ (ca. 77-79) in which according to himself he had compiled "20,000 important facts, extracted from about 2000 volumes by 100 authors" and was written for "the common people, the mass of peasants and artisans, and only then for those who devote themselves to their studies at leisure" (Preface 6). This is the earliest known encyclopedia of any kind, which has been interpreted as a Roman invention in order to compile information about the empire (Naas 2002, Murphy 2004). It was a rather disorganized book, whose prose has been criticized by many (Locher 1984). Pliny seemed to be more interested in what appeared to be curiousities than what were facts. This is a big collection of facts and fictions, based mostly said on things said by others.

He devoted 9 of the 37 volumes to animals and ordered them according to where they live. Volume IX (Historia Aquatilium) of Naturalis Historia is devoted to aquatic creatures, whether living in oceans, rivers or lakes, whether vertebrate or invertebrate, real or mythical. Based on their size he categorized as "monster" anything big, whether it is a whale, a sawfish or a tuna (IX 2,3).

He grouped together all known species of cetaceans (cete) but constantly mixed their descriptions with those of other marine mammals such as seals as well as with cartilaginous fishes, such as some sharks (pristis). Pliny mentioned the three species cited by Aristotle: dolphins (delphinus, probably a combination of striped dolphin [Stenella coeruleoalba] and the common dolphin [Delphinus delphis], IX 12-34), porpoises (porcus marinus, the harbor porpoise [Phocoena phocoena], IX 45) and whales (ballaena, possibly a combination of large toothless whales [mysticetes] IX 12-13). Then he added a few more: the thursio or tirsio (probably the bottlenose dolphin, Tursiops truncatus IX 34), the physeter (probably the sperm whale [Physeter macrocephalus] IX 8) found in the "Gallic Ocean" (probably the Bay of Biscay, IX 3, 4), the orca (probably the killer whale [Orcinus orca] IX 12-14), and the river dolphin from India (possibly Platanista gangetica, IX 46). He also mentioned some mythical creatures such as Homo marinus (Sea-Man, IX 10) and the Scolopendra marina (IX, 145) a mythical

\footnotetext{
${ }^{6}$ b. as Gaius Plinius Secundus 23/24 CE in what is now Como, Italy; $d .25$ August 79 CE near Pompeii, Italy.

${ }^{7}$ I used the version available at:

http://www.perseus.tufts.edu/hopper/text?doc=Plin.+Nat.+toc\&redirect=true
} 
organism whose legend may be based on polychaetes, marine annelids characterized by the presence of many legs (Leitner 1972, p. 218).

Pliny recognized that neither whales nor dolphins have gills, that they suckle from the teats of their mothers, and that they are viviparous. In addition to these true facts copied from Aristotle, he mentioned exaggerations such as whales of four jugera (ca. $288 \mathrm{~m}$ ) in length that because of their large size "are quite unable to move" (IX 2,3). In addition to some of the biological facts mentioned by Aristotle, Pliny adorns his narrative with all kind of casual tales about interactions between cetaceans and humans.

By lumping together all kinds of aquatic organisms it is hard to distinguish what he called "fish" and what he did not (see for example IX 44-45). His classification took a step back from Aristotle because he did not try for a comprehensive classification of animals. He failed to compare organisms based on shared or divergent characters. Many times he ordered creatures based on size, from the largest to the smallest. Yet, his work had great influence for 1700 years, which was unfortunate because he was an uncritical compiler of other people's writings (even if they were contradictory). Pliny also created a number of unfounded impressions about the reality of nature. His only positive contribution was that he established the norm of always citing the sources of his information (in actuality 437 authors, whose works, in some cases, are no longer available).

\section{Medieval times}

During the middle ages, little progress was made in the sciences. Students were urged to believe what they read and not to question conventional wisdom. Logic determined truth, not observation. Free thought was non-existent and minds were filled with mythological explanations for the unknown. Marine mammals were depicted as monsters and little new information was generated.

\section{The renaissance}

The Renaissance was a time of awakening and the religious ideology began to be questioned. The translations of the works of Aristotle and Pliny into Latin and the introduction of the printing press helped to spread the little knowledge accumulated until that time about natural history in the western world. For example, by 1500 about 12 editions of Aristotle's Historia Animalium and 39 of Pliny's Historia Naturalis had seen the light, which is evidence of the popularity of these works. During this age of discovery the finding of species that were never mentioned neither by Aristotle nor the Bible, opened up scientific curiosity about new creatures around the world. Thus, people once again began to seek new knowledge. However, in these times, naturalists were more compilers of information than investigators despite the fact that they were performing more dissections that in turn uncovered new taxonomic possibilities. Still, scientists relied on environmental aspects to classify animals. Collecting was a primary activity during this era (Alves 2010, p. 54). 


\subsection{Pierre Belon}

Belon $^{8}$ was the first author studying marine mammals in this historical period. Little is known about his family and early years. He traveled extensively throughout Europe and the Middle East, including the Arabian Peninsula and Egypt. Among the places he visited were Rome where he met two other ichthyologists, Rondelet and Salviani (see below). He studied medicine at the University of Paris and botany at the University of Wittenberg, Germany. He served as a doctor and apothecary for French kings, as well as a diplomat, traveler, and as a secret agent (he was murdered under strange circumstances) (Wong 1970).

His L'Histoire Naturelle des Estranges Poissons Marins (1551) was the first printed scholarly work about marine animals. This book was expanded and published in French in 1555 as $\mathrm{La}$ Nature et diversité des poissons including 110 species with illustrations for 103 of them.

Belon not only reproduced information from Aristotle and Pliny but also added his own observations including comparative anatomy and embryology. For him "fish" was anything living in the water. He divided "fishes" in two large groups: the first was "fish with blood" (as Aristotle had done) that included not only actual fishes but also cetaceans, pinnipeds, marine monsters and mythical creatures such as the "monk fish," as well as other aquatic vertebrates such as crocodiles, turtles, and the hippopotamus. He called a second group "fishes without blood" and consisted of aquatic invertebrates (see also Delaunay 1926).

He ordered what we know as cetaceans today in a vaguely descending order based on size: Le balene (mysticete whales, although in the illustration he depicted a cetacean with teeth), Le chauderon (sperm whale? although he mentions the sawfish), Le daulphin (common dolphins on which he devoted 38 pages of this 55-page book), Le marsouin (porpoise), and L'Oudre (bottlenose dolphin) (for a rationale on the identification of these species see Glardon 2011, p. 393-398). He dissected common dolphins (D. delphis) and porpoises (P. phocaena) acquired at the fish market in Paris brought in by Normandy fishers, and probably a bottlenose dolphin (T. truncatus) as well.

He described these marine mammals as having a placenta, mammae, and hair on the upper lip of their fetus. Belon wrote that apart from the presence of hind limbs, they conform to the human body plan with features such as the liver, the sternum, milk glands, lungs, heart, the skeleton in general, the brain, genitalia. He also dealt with issues of breathing and reproduction (although from the description it is clear that he never saw one of these animals giving birth, since he depicted the newborn surrounded with a membrane). He drew the embryo of a porpoise and the skull of a dolphin (Fig. 1). Despite all this he did not make the connection between cetaceans and "viviparous quadrupeds" and based his entire classification on environmental foundations, as he made clear in the introduction of his work.

\subsection{Edward Wotton}

Wotton ${ }^{9}$ was the son of a theologian who did general studies at Oxford and studied medicine and Greek at Padua (1524-6). He was a practicing physician who published De

\footnotetext{
8 b. 1517, Soultière, near Cerans, France; $d$. April 1564, Paris, France.

${ }^{9}$ b. 1492, Oxford, England; $d .5$ October 1555, London, England.
} 


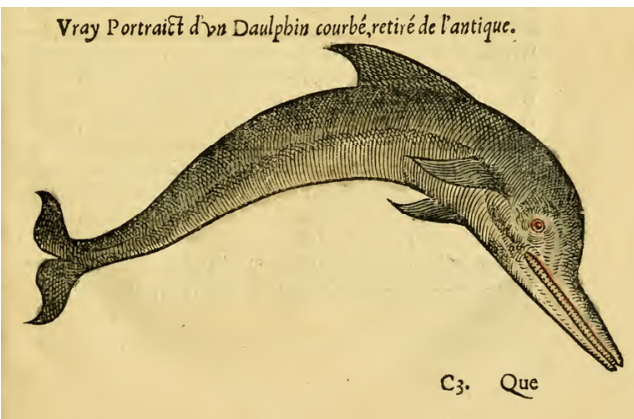

(a)

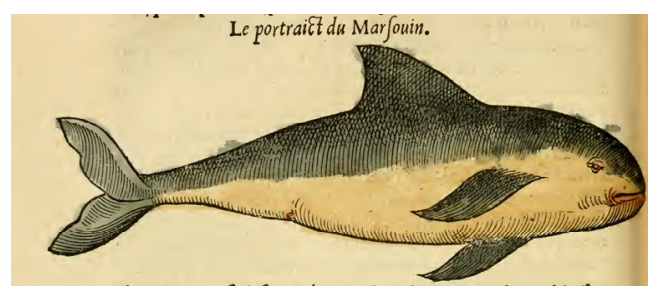

(c)

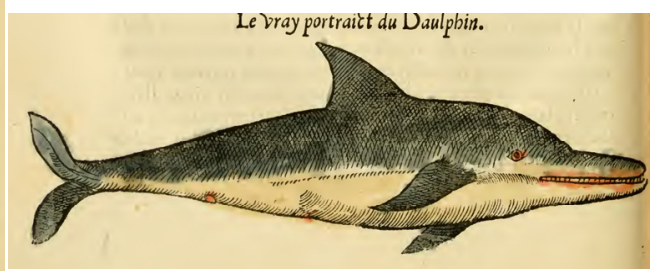

(b)

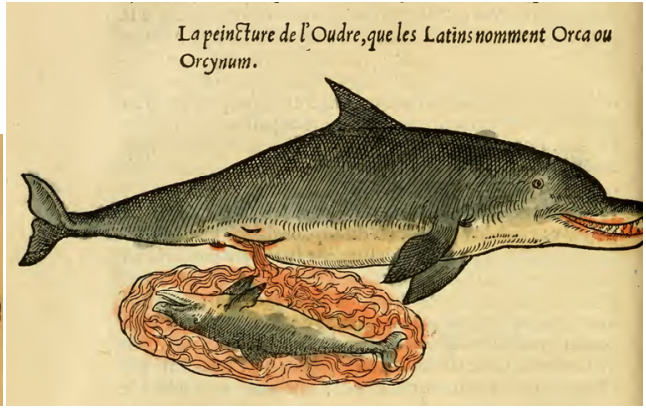

(d)

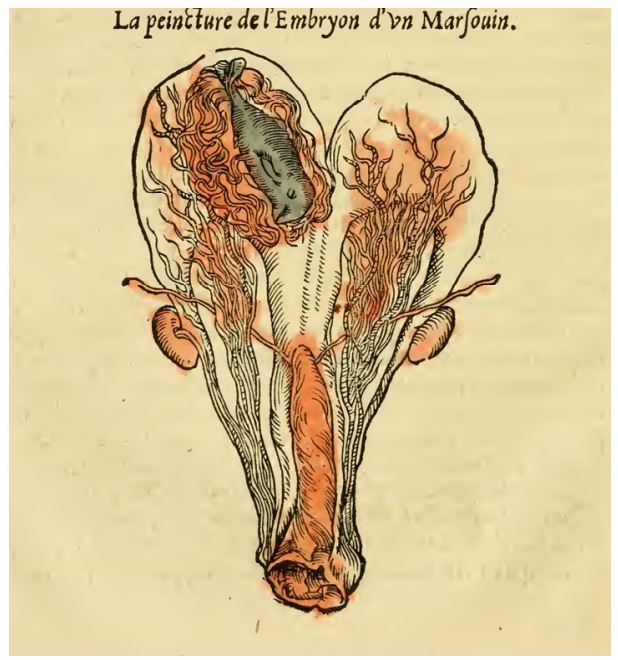

(f)

(e)

Figure 1. Illustrations of marine mammals by Belon (1551): (a) and (b) are representations of the common dolphin (Delphinus delphis); (c) a porpoise (Phocaena phocaena); (d) a bottlenose dolphin (Tursiops truncatus, although he uses the name of "Orca") presumably giving birth; (e) the skull of a dolphin; (f) a porpoise fetus in a placenta, showing that he had actually dissected these animals. 
Differentiis Animalium Libri Decem (1552), probably the first published book on natural history of the Renaissance. This was a 10-part ("books") treatise that followed the classification structure by Aristotle while adding some comments from Pliny. In Book 8 (pp. 171-173) he placed Cete together with fishes because of the medium they inhabit. Except for entomology he did not conduct any original observations on animals nor include any illustrations. His contemporaries noted his lack of originality (Nutton 1985).

The list of cetacean species included Delphino (dolphins), Phocaena (porpoises), Balaena (mysticete whales), Orca (either the bottlenose dolphin or the killer whale) and Physeter (the sperm whale).

\subsection{Guillaume Rondelet}

Rondelet ${ }^{10}$ was the son of a drug and spice merchant. He studied medicine at the University of Montpellier, one of the best medical schools in Europe at that time. While in Paris he studied anatomy under Johannes Guinther, who also taught Vesalius. Rondelet would later become Professor of medicine and Chancellor at Montpellier (Keller 1975). He probably acquired his interest in ichthyology at a young age while living in Montpellier (about $12 \mathrm{~km}$ from the coast) because his family owned a farm that was a stopping place for carts of fish from the Mediterranean (Oppenheimer 1936). During his trips as personal physician to Francois Cardinal Tournon (who was also the patron of Belon) to the Atlantic coasts of France, he became acquainted with the whaling industry. Rondelet met several contemporary ichthyologists while in Rome (1549-1550) such as Belon, Hippolyto Salviani, and Ulyssis Aldronvandi (Gudger 1934). Guillaume Pellicer, Bishop of Montpellier, who was also interested in fishes but never published on ichthyology, may have influenced Rondelet (Oppenheimer 1936, Dulieu, 1966).

He enjoyed dissecting and did so frequently for both teaching and research purposes. He published Libri de Piscibus Marinis in quibus verae Piscium effigies expressae sunt (1554) with a second part titled Universae Aquatilium Historiae pars altera (1555) about both marine and freshwater animals. Both were later translated into French as L'histoire entière des poissons $(1558,599)$, a monograph for teaching purposes.

After writing about food, habitat, morphology, and physiology, he described 145 freshwater and 190 marine species that included at least seven species of cetaceans: delphino (common dolphin), phocaena (porpoise), tursione (bottlenose dolphin, although the illustration more resembles a porpoise), balaena vulgo and balaena vera (two different species of mysticetes whose true identities are difficult to ascertain), orca (killer whale), and physetere (sperm whale) (Fig. 2). He also included among cetaceans the priste (sawfish) and mythical animals such as Pliny's scolopendra cetacea, the monstruo leonino (a lion covered with scales and with a human face), the pisce monachi habitu (a fish that looks like a monk), and the pisce Episcopi habitu (a fish that looks like a bishop) of which he was skeptic. All together his book contained more species than previous published works. Each species description included

${ }^{10}$ b. 27 September 1507, Montpellier, France; $d .30$ July 1566, Réalmont, Tarn, France 
the animal's name in different languages, their morphology (external and internal), feeding habits, and use as food for humans. Species were differentiated similarly to Aristotle as blooded and non-blooded. Although Aristotle inspired the entire book, including teleological considerations in his discussions, Rondelet added some original ideas, especially concerning anatomy and descriptions of the small cetaceans he dissected. Rondelet made correlations between form, function, and environment.

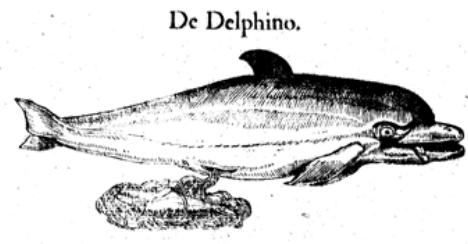

(a)

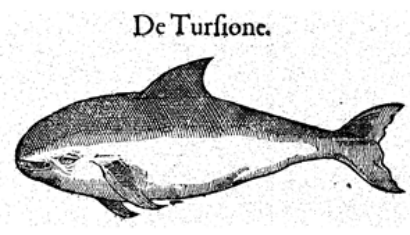

(b)

De Balrna vulgò dieta fiue de Mufculo.

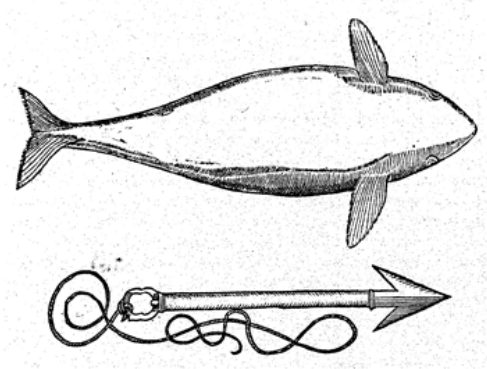

(c)

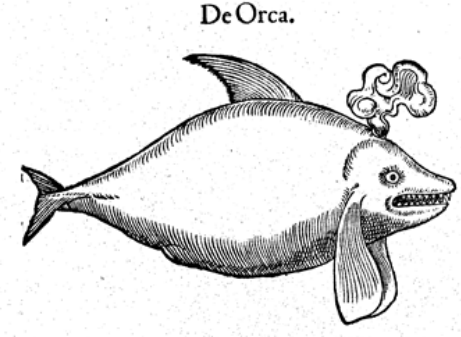

(e)

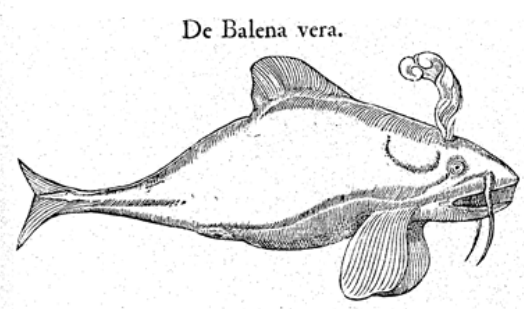

(d)

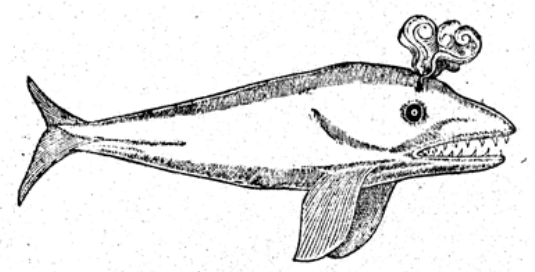

(f)

Figure 2. Illustrations of marine mammals by Rondelet (1554): (a) a dolphin showing a fetus surrounded by a placenta indicating it was a viviparous animal; (b) a porpoise; (c) an unidentified species of mysticete, probably a right whale because may have been observed by Rondelet during a whaling operation in the Atlantic; (d) an unidentified species of mysticete that he never saw as evidenced by the depiction of barbels above the mouth; (e) orca (Orcinus orca); (f) a sperm whale (Physeter macrocephalus). 
Despite noting differences, he grouped marine mammals with fish based on habitat. For example, he noted that fishes with scales lack lungs and have a three-chamber heart while what we know today as marine mammals have hearts with four chambers. He compared the anatomy of a dolphin to that of the pig and humans. Based on this and his descriptions of other internal organs, he considered marine mammals to be a type of aquatic quadruped. Yet, he did not propose a system of classification. He did not advance the notion of valid classification, but because of the quality of his descriptions his work remained as the main reference for about 100 years.

\subsection{Conrad Gessner}

Gessner ${ }^{11}$ probably developed an interest in zoology after seeing the carcasses of furred animals at his father's workshop where several furriers worked. He also lived with a greatuncle, an herbalist, who furthered his interest in natural history (Bay 1916, Gmelig-Nijboer 1977, p. 17, Wellisch 1984, p. 1). He was an avid traveler who studied theology and medicine in Bourges, Paris, Montpellier, and Basel (Fischer 1966) and had great facility for classical languages. During his travels Gessner met with Belon and Rondelet. He is considered as the "father of bibliography" because of his work on compiling information about books (Bay 1916). Gessner himself had a very large private library of more than 400 volumes (which was a very large private collection for his time) of which $19 \%$ of the volumes were on natural history and 13 of them were on zoology (Leu et al. 2008, pp. viii, 1, 13, 21). He published Historiae Animalium (1551-1558), an encyclopedic (4 volumes, 4,500 pages treatise) but uncritical compilation of information and bibliography in which he intended to itemize all of God's creations. In addition to classic authors such as Aristotle and Pliny, Gessner obtained information from whomever he could correspond. He classified cetaceans among 'aquatic animals,' i.e., including fishes. The fourth volume (Piscium \& Aquatilium) of 1297 pages was published in 1558 and was about the aquatic animals. A fifth volume on reptiles and arthropods was not published until 1587, posthumously. Historiae was added to the list of prohibited books because Gessner was Protestant. Yet, the 14 editions in different languages of this book reveal its popularity.

Gessner followed Aristotle's classification of animals when it came to their grouping by volume (Vol. 1: viviparous quadrupeds; Vol. 2: oviparous quadrupeds; Vol. 3: birds; Vol. 4: aquatic animals; Vol. 5: serpents). He ordered them alphabetically, like a "Dictionarium," in each volume, which did not provide a rational classification based on relationships of any kind; on the other hand this alphabetical order facilitated its use as an encyclopedic source. Gessner's intention was to collect any piece of information ever written about each animal by any author in history, he cited nearly 250 authors including Rondelet (Libri de Piscibus Marinis, 1554), Belon (De Aquatilibus,1553), and Salviani (Aquatilium Animalium, 1554). The latter only mentioned marine mammals in passim.

${ }^{11} b .16$ March 1516, Zürich, Switzerland; $d .13$ December 1565, Zürich. 


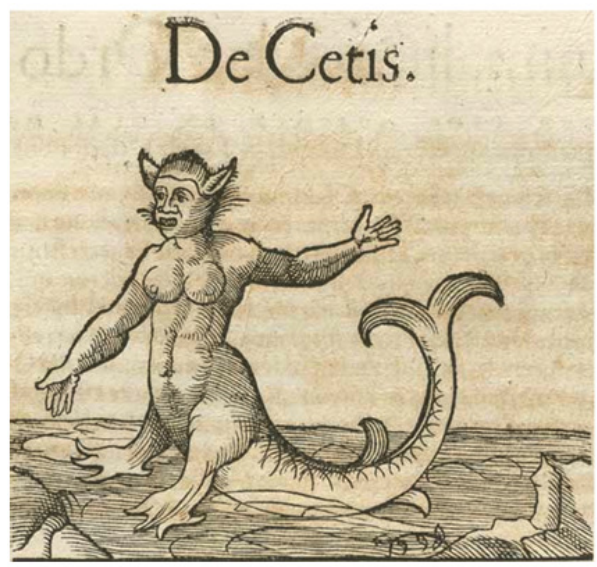

(a)

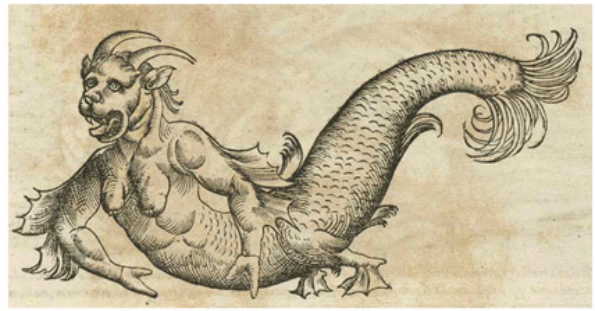

(b)

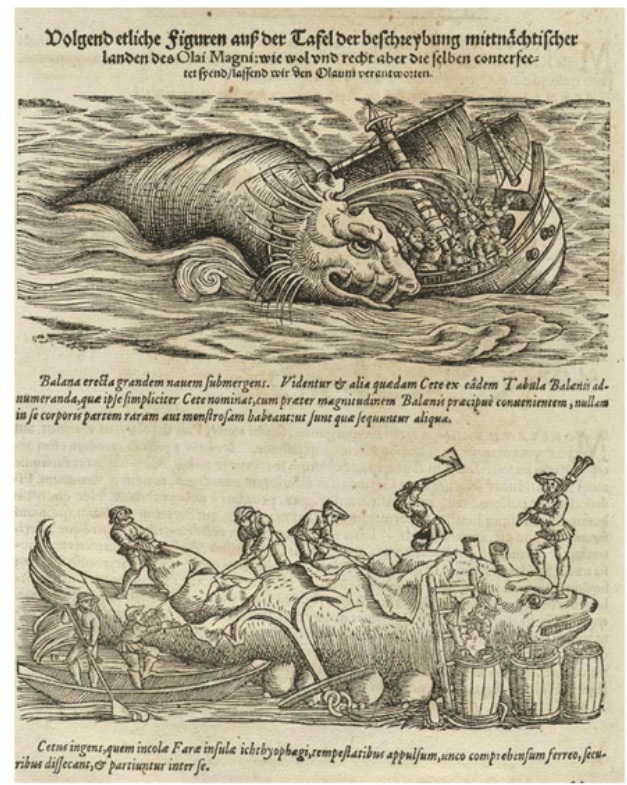

(c)

Figure 3. Some of the "Cetis" described by Gessner (1558): (a) and (b) two examples of marine monsters; (c) a whale attacking a ship and another being flensed during whaling operations. Both show mysteces with teeth, which indicates that Gessner never saw these animals. This exemplifies that Gessner was an uncritical compiler of information.

Information included names of the animals in various languages (some times more than a dozen) comprising epithets and etymology (even inventing common names in other 
languages when those names were not available), physical features, geographic distribution, the animal's way of living including diseases and their cures, behavior, utility towards man (e.g., for food or medical purposes), and tales. His work was full of illustrations: some were very accurate showing that he had first-hand knowledge of the animal in questions while other were bizarre or just invented, especially when dealing with mythical creatures.

Gessner included a 16-page-folio discussion about the dolphin very much along the lines of Aristotle and Pliny. As an uncritical compiler he included contradictory or totally false information such as mythical species and even "monsters." In volume 4 he relied heavily on Belon and Rondelet. For example, Monachus marinus (sea monk, IV, p. 519) description was copied from Rondelet who, in turn, had received the description from Marguerite, Queen of Navarre, who heard it from Emperor Charles V's ambassador, who had claimed to see the monster himself (Kusukawa 2010). He did not add much to what was already known. Among marine mammals he mentioned are the Balaena (mystecete whales, IV, p. 128) depicted more as sea monster than as an actual whale, Cetis diversis (IV, p. 207), an amalgam of marine monsters based on Olaus Magnus's descriptions of sea monsters from seas from northern Europe, Hominis marinis (IV, p. 438), a collection of humanoid sea monsters such as the sea-monk and the sea-bishop. To certain extent he was skeptical of accuracy of some of these descriptions by other authors.

Many of the figures were made by others and copied directly from other books including those of "cetaceous" animals as was the case of a whale which was copied from Olaus Magnus' map of the Northern Lands (IV, p. 176) (Fig. 3).

\subsection{Ulysses Aldrovandi}

The last author who published anything of significance about marine mammals during the Renaissance was Aldrovandi ${ }^{12}$. He was born to a noble and wealthy family, which allowed him to initially dedicate his life to his own pursuits. He was educated in Bologna, Padua, and Rome, receiving degrees in law and medicine although he never practiced those professions. He was appointed as the first professor of natural history in the University of Bologna. Although he was a pious Catholic, because of what he read he was charged with heresy. After producing himself in Rome, he was acquitted. While in Rome he met Rondelet and accompanied him to the fish markets where he became interested in ichthyology (which included the study of marine mammals) collecting specimens for his own museum. He traveled extensively throughout Italy and made a collection of about 11,000 animal specimens for pedagogical purposes; most of them can be found today at the Bologna Museum to which he bequeathed not only his specimens but also his library and unpublished manuscripts as well (Alves 2010, pp. 56-82). He also conducted dissections (Impey and McGregor 1985). He was a true encyclopedist following the tradition of the University of Bologna at that time (Tugnoli Pattaro 1994). He wrote extensively but the quality of his animal descriptions and illustrations were poor from the scientific viewpoint

12 b. 11 September 1522, Bologna, Italy; d. 4 May 1605, Bologna. 
(Fig. 4). Aldrovandi was an uncritical compiler who included legends of mythical animals in his writings similar to the medieval bestiaries and in the tradition of Pliny.

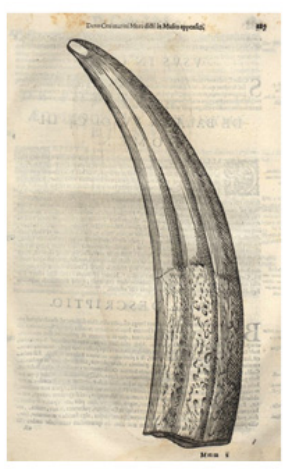

(a)

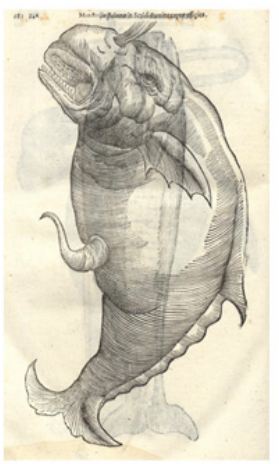

(e)

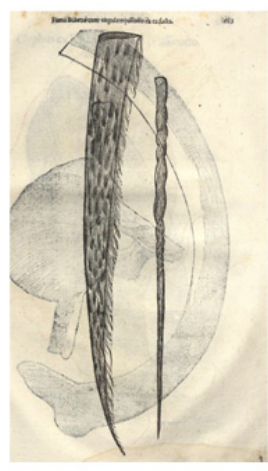

(b)

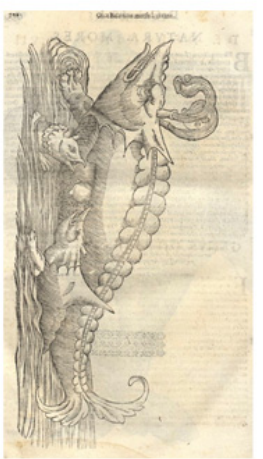

(f)

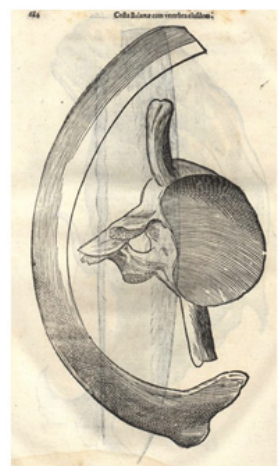

(c)

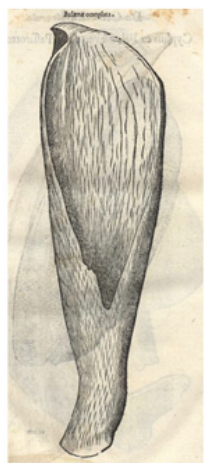

(d)

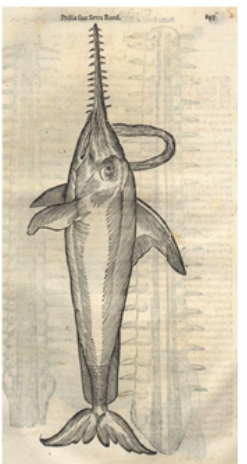

(g)

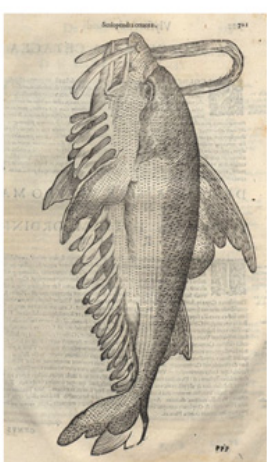

(h)

Figure 4. Depiction of some marine animals by Aldrovandi (1613): Some show that he actually saw some of those skeletal pieces such as (a) a tooth possible from a sperm whale, (b) a baleen and the prominent tooth of a narwhal (Monodon monoceros), (c) a rib and a vertebra, possibly of a large whale, and (d) a scapula. In other cases he illustrated whales with human-like emotions (e); whales with feet (f); sawfishes with cetacean characteristics (g); and Pliny's "Scolopendra cetacea" (h), which perpetuated the notion that such animal existed. Overall he was a very uncritical compiler when it came to marine mammals.

He published De piscibus libri V, et De cetis lib. vnus (1613) where he defined "Pisces" as animals covered with scales and "aquatilis" as "anything else that lives in the water" while recognizing that cetaceans are air-breathing creatures. The species that he mentioned were the ones cited by his predecessors: Balaena, Physeter, Orca, Delphino, Phocaena, and Tursione, while including the Manate Indorum, Phoca, Pristi (the sawfish), and the mythical Scolopendra 
Cetacea. From the illustrations (Fig. 4) it is clear he never saw any of these animals with the exception of some of their skeletal parts. As an uncritical compiler of information he did not add anything new to the knowledge of these creatures and, yet, was cited by later authors.

\section{Modern science}

In this period, observation and experimentation moved to the forefront of science. Classification was based on similarities and differences in characters. During this time English physicians travelled to Padua, Bologna and Paris to be trained in human dissection since the status of medicine in England was still poor. People involved in these kind of activities had a background in either medicine (or "physic" as it was called then) and/or theology (Kruger 2004). During this time the center of gravity of science moved from the Mediterranean world to northern Europe, mostly England.

\subsection{Johann Jonston}

The first researcher of the biology of marine mammals in this period was Johann Jonston ${ }^{13}$. Although born in Poland, Jonston's father was Scottish and his mother German. He was educated in St Andrews, Frankfurt, Cambridge, and Leiden, receiving a medical degree from the last two institutions. He traveled extensively throughout Europe teaching, and despite offers for academic positions, he decided to make a living as an independent scholar (Miller 2008). He published Historiae naturalis de Piscibum Partem in 1657. Jonston was another encyclopedist who when it came to natural history was more a compiler than anything else, relying heavily on Gessner and Aldrovandi while adding some new information from New World creatures from George Marcgrave. Thus, he did not offer any significant critical view to his sources although his descriptions were briefer than those of his predecessors. He gave no hint of biological classification for marine mammals and also added further mistakes and legends (even 'monsters'). He slightly modified Aldrovandi's classification of fishes by adding 'pelagic' fishes. Yet his books were widely read and translated.

He dealt with cetaceans on pages 213-224 of his Historiae and included the same species as Aldrovandi: Balaena, Physetere, Orca, Delphino, Phocaena and the mythical scolopendra cetacea, the sawfish, pinnipeds, and the manatee among the cetaceans.

\subsection{Walter Charleton}

Charleton ${ }^{14}$ was the son of a church rector of modest means. He was educated at Oxford as a physician at that time when medical education in England emphasized scholastic approaches to knowledge and British colleges had inadequate anatomical staff and teaching facilities. The practical elements of practicing medicine were not acquired until after assisting a more experienced practicing medical doctor.

\footnotetext{
${ }_{13} b .15$ September 1603, Szamotuly, Poland; $d .8$ June 1675, Legnica, Poland.

${ }^{14}$ b. 2 February 1619, Shepton Mallet, Somerset, England; d. 24 April 1707, London, England.
} 
Charleton was a follower of epicurean atomism (materialism) (Kargon 1964) and an eclectic (Lewis 2001), whose interest in natural history was more or less theological because, as he said, men were obligated into "naming \& looking into the nature of all Creatures" (Boot 2005, p. 119). In other words, just as Ray and Willoughby did later, natural science was the search a divine pattern in nature, part of the research agenda of the Royal Society - to which Charleton belonged (Rolleston 1940, Sharpe 1973). His publications showed him more as a compiler than as an innovator. His major contribution to science was the discovery that tadpoles turn into frogs (Booth 2005, p. 1).

He published two books dealing with animal classification: Onomasticon zoicon (1668) and Exercitationes de Differentiis \& Nominibus Animalium (1677) works that listed the names of all known animals (including some fossils) in the western world in several languages with a somewhat taxonomy discussion, including remarks about these animals habits and habitats that contained anatomical descriptions of two animals that he had dissected. As Belon did over a century before, he divided "fishes" as either "with blood" (vertebrates) and "without blood" (invertebrates). He grouped under "Cetaceos" not only actual cetaceans but also the sawfish, seals, walruses, manatees, hippopotamus and the mythical "scolopendra cetacea." The actual cetaceans described were Balaena vulgaris (probably the right whale), Physeter, $\mathcal{E}$ Physalus (probably the fin whale but also other species), Cetus dentatus (the sperm whale), Pustes (indeterminate species, maybe the beluga), Orca (the killer whale), Monoceros (the narwhal), Delphinus (probably a composite of delphinidae), and Phocaena (the porpoise).

\subsection{Edward Tyson}

Tyson ${ }^{15}$ was born into an affluent merchant family. He performed numerous dissections as a college student, obtained his medical degree at Oxford University and was a lecturer of Anatomy at the Barber-Surgeons Hall in London. Tyson was the first of the comparative anatomists in the modern sense. He did extensive dissections and was the first to use a microscope as part of his anatomical studies. His description of the highly convoluted cetacean brain as well as his recognition of the many homologies with "viviparous quadrupeds", rather than the fishes that they externally resembled, constituted a major landmark contribution to the history of biology (Kruger 2003).

In Phocaena, or, The anatomy of a porpess dissected at Gresham Colledge, with a preliminary discourse concerning anatomy and natural history of animals (1680), he noted that "What we have here is a signal Example of the same between Land-Quadrupeds and Fishes; for if we view a Porpess on the outside, there is nothing more than a fish; for if we view a Porpess on the inside, there is nothing less. (...) It is viviparous, does give suck, and hath all its Organs so contrieved according to the standard of them in Land-Quadrupeds; that one would almost think of it to be such, but it lives in the Sea, and hath but two fore-fins." Adding later "The structure of the viscera and inward parts have so great an Analogy [sic] and resemblance to those of Quadrupeds, that we find them here almost the same. The greatest

${ }^{15}$ b. 20 January 1651 Clevedon, near Bristol, Somerset, England; d. 1 August 1708, London, England. 
difference from them seems to be in the external shape, and wanting feet. But here too we observed that when the skin and flesh was taken off, the forefins did very well represent an Arm, there being the Scapula, an of Humeri, the Ulna, and Radius, and bone of the Carpus, the Metacarp, and 5 digiti curiously joynted. The Tayle too does very well supply the defect of feet both in swimming as also leaping in the water, as if both hinder feet were colligated into one, though it consisted not of articulated bones but rather Tendons and Cartilages."

Tyson's description of the internal anatomy of the porpoise is remarkable, particularly when it comes to its nervous system (Kruger 2003). In many ways he thought that the "porpess" was the transitional link between terrestrial mammals and fish.

In his monograph Tyson surveyed contributions from previous authors. He corresponded with John Ray (see below). Ray had also dissected a porpoise (an exercise on which he reported in a published form in 1671), nine years before Tyson but was far more superficial and added very little to what other authors such as Rondelet had done. Tyson met Ray around 1683 and the latter invited Tyson to contribute to Willughby's De Historia Piscium (Montagu 1943, p. 103).

Tyson was critical of encyclopedic approaches and relying on classical authors when it came to natural history. He set new standards in terms of direct observation and comparative anatomy. He also established an understanding of homology not seen since Aristotle. He proved to be a very competent observer of internal anatomy and he saw comparative anatomy as a means to explain the Great Chain of Being (or scala naturae or ladder of nature) as proposed by Plato and Aristotle.

\subsection{Samuel Collins}

A contemporary of Tyson was Samuel Collins ${ }^{16}$. The son of the rector of Rotherfield, Sussex, who got his education at Cambridge, Collins travelled to several universities in France, Italy and the Netherlands finally getting his medical degree at the University of Padua, later becoming physician of Charles II. He taught anatomy at the Royal College of Physicians ${ }^{17}$. Collins published A Systeme of Anatomy (London 1685), which was the earliest attempts to illustrate the brains of a broad variety of mammals, birds, teleosts, and elasmobranchs in a remarkable two-volume folio edition of 1,263 pages. It included 73 full-page illustrations of very high quality. There he described a female porpoise. However, it seems that he had used Tyson's previous descriptions and unfortunately says nothing about the brain of this cetacean. Had he had examined the brain of the porpoise he would have noted the great similarities of this organ with those among the "viviparous quadrupeds." Collins did not discuss the similarities between the other internal organs of the porpoise and those called mammals today either. He acknowledged Tyson' previous contributions in this matter.

\footnotetext{
${ }^{16}$ b. 1618, Rotherfield, Sussex, England; $d .11$ April 1710, Westminster, Middlesex, England.

${ }^{17}$ Biographical information obtained from: http://munksroll.rcplondon.ac.uk/Biography/Details/950 and accessed on 2 April 2012.
} 
In addition to Tyson, Collins's anatomy draws largely upon the works of Thomas Willis. In the opening Epistle-Dedicatory to James II he claimed that various chapters "are illustrated by the Dissection of other Animals (which I have performed with Care and Diligence, speaking the wonderous Works of the Glorious Maker) rendering the Parts of Man's Body more clear and more intelligible." In volume two of his huge work he described numerous folio copper plates containing the most extensive comparative anatomy of the brain then existing, an expansive account of the functional significance of his findings, as well as practical clinical commentary.

\subsection{John Ray}

Ray $^{18}$ was the first naturalist who truly represented this new era of careful observation. His father was a blacksmith and his mother was an herbal healer. He studied at the University of Cambridge, pursuing comparative anatomy although initially his main interest was botany. He taught Greek, mathematics and humanities at Cambridge but abandoned his teaching position after refusing to comply with the Act of Uniformity of 1662. He was a very religious person who undertook the study of nature to understand God's creation (Raven 1950). Fairly early he developed a plan with his student and patron, Francis Willughby ${ }^{19}$ to produce a joint general natural history. To that end Ray and Willughby went on an extended tour of England and Europe (1662-1666), including the medical school at Montpellier. Although they did not always travel together both collected specimens, got involved in dissections and acquired books and illustrations (Kusukawa 2000), an endeavor bankrolled by Willughby. When Willughby died, Ray took over his parts of the general natural history. Willughby left him an annuity of $£ 60$ and Ray stayed on as tutor to Willughby's children until 1675, when Willughby's mother, also his patron, died, and the widow immediately terminated the relationship. Ray inherited a small farm that also contributed to the family's maintenance while he earned money from his productive publishing. Therefore Ray had the financial freedom to pursue his intellectual interests.

Ray's first published work on cetaceans was Dissection of a Porpess (1671). He does a much better job in describing the internal anatomy of this animal when compared with Rondelet but does not get into the detail that Tyson achieved later. During the narrative of his findings he keeps noticing that a porpoise has a lot in common with the "quadrupeds". Yet he persisted calling them "fishes."

Ray published Historia piscium (1686), under Willughby's name 14 years after his patron death, though Ray himself contributed the vast majority of the content. He carried out the first serious attempt to achieve a systematic arrangement, the success of which can be attributed by the fact that it served as a basis for the systematics work of the following

18 b. 29 November 1627, Black Notley, near Brainton, Essex, England; d. 17 January 1705, Black Notley, England.

${ }^{19}$ b. 22 November 1635, Middleton, Warwickshire, England; $d .3$ July 1672, Middleton. 
century. His approach was based on direct observation, collaboration with other researchers, and critical reading of previous authors.

Historia Piscium is divided into two parts that were printed separatedly: the first is the narrative and the second, titled Ichthyographia, were the illustrations. Many libraries today have both bound together. As sources Ray used authors mentioned earlier in this chapter: Rondelet, Salviani, Gessner, Aldrovandi and Belon, among others. Yet, far from merely compiling information from them, Ray insisted in very comprehensive descriptions of species and discarded all monsters and mythical creatures mentioned by his predecessors. Ray not only removed narratives of marine invertebrates but also other aquatic animals such as the crocodile and the hippopotamus. He divided his subject matter into three groups: cetaceans, cartilaginous fishes, and bony fishes. He recognized that when it comes to reproduction and internal anatomy cetaceans are identical to the "viviparous quadrupeds." Still, he kept cetaceans within the "piscium" despite the fact that he was well aware that they were biologically distinct from fishes.

In his narrative of species Ray moved away from in the practical aspects related to these animals. Aspects such as usage for medical purposes were very common among previous authors because of their medical background. Yet, Ray was very keen at compiling names on the belief that a universal language could be construct based on the knowledge of nature. As Kusukawa (2000) has argued convincingly, Ray believed that there was a need for "a construction of a universal language based on a table that properly expressed the natural order and relations between things." Hence a precise description and classification was the route to achieve that goal. The final product counted not only on the intellectual support of the Royal Society's members who provided constructive criticism and moral support but also their financial support. The cost of publishing Historia Piscium was not only very high, mostly because of the expense of the illustrations (187 plates), but also the 500 copies printed sold poorly. As a consequence the Society could not print Isaac Newton's Principia.

Ray's third publication related to marine mammals was Synopsis Methodica Animalium Quadrupedum et Serpentini Generis (1693). By then he was totally convinced that cetaceans were not fishes: "For except as to the place on which they live, the external form of the body, the hairless skin and progressive swimming motion, they have almost nothing in common with fishes, but remaining characters agree with the viviparous quadrupeds." He placed today's terrestrial mammals (including the manatee) among the 'hairy animals' very close to the Cetaceum genus (cetaceans).

In Synopsis Ray included a section called Pisces Cetacei seu Belluae marinae where he expressed that these animals breath and give birth like the "oviparous quadrupeds." He grouped them into two categories according to the presence of teeth much as we do today separating odontocetes from mysticetes. Ras was the first in doing so. The species he cited were Balaena vulgaris (Rondelet), Balaena (Fin-Fish), Physeter or Balaena physeteris, Orca (Rondelet \& Belon), Cete (Sperm whale), Pot Walfish, Albus piscis cetaceus (white fish), Monoceros cetaceo (Narhual islandis), Delphino antiquorum (dolphin, from Rondelet), Phocaeno (Rondelet \& Belon), dissecting a specimen of the latter in 1669. 

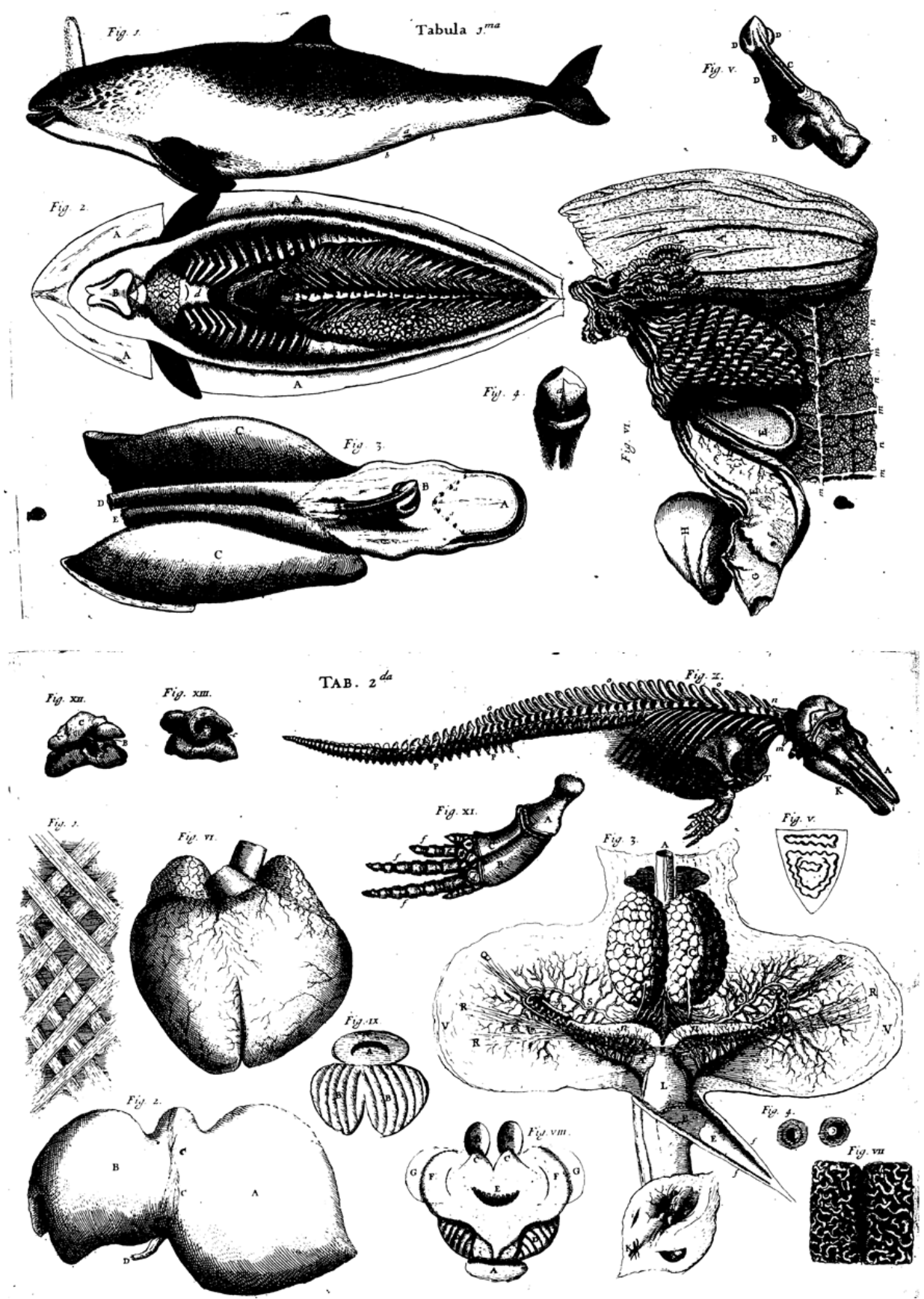

Figure 5. Illustrations from Tyson's (1680) description of the internal anatomy of a porpoise. Notice the remarkable accuracy of the depictions. 
Ray developed a division of animals characterized by having blood, breathing by lungs, two ventricles in the heart, and being viviparous. Ray subdivided this group into aquatic (cetaceans) and terrestrial or quadruped including sirenians (manatees and dugongs). He rejected tales of fabulous animals while perfecting Aristotle's classification by diving vertebrates into those having hearts with two ventricles (mammals and birds) from those with a single ventricle (reptiles, amphibians and fish). He also advanced the understanding of other groupings. He established the significance of the generic principle, defined species, and was a leading contributor to the gigantic task of classification.

Ray came close to recognizing mammals as a separate group based on "warm-blood," vivipary, and hair. He conceded the relationship of cetaceans with viviparous quadrupeds; described genera and species; established ordinal classification of mammals; systematic phrases and names; used of descriptive phrases as well as monomial names (a taxonomic name consisting of a single word); a dichotomous ("A is B or not B") classification of mammals. Yet, he lacked the vision or intellectual courage to reunite marine mammals with their terrestrial relatives and still placed the former with the fish "in accordance with common usage." Still he was possibly the best naturalist of the seventeenth century.

\subsection{Peter Artedi}

Artedi ${ }^{20}$ was the son of a parish priest who developed an interest in fishes from an early age. He studied medicine at the University of Uppsala, devoting most of his time at studying natural history. At 29 years of age he went to London for a year to study natural history collections and described the sighting of a whale in November 1734, probably downstream of the London Bridge. He then moved to Leiden, The Netherlands, to complete his medical studies and there he met Linnaeus, whom he knew from their native Sweden, forging a lifelong personal and professional relationship. Linnaeus introduced him to an Amsterdam chemist, Albert Seba, and Artedi started working on Seba's fish collection. Artedi died at the age of 30 by drowning in an Amsterdam canal. After his death, Linnaeus recovered his manuscripts and published Ichthyologia (1738) without amending Artedi's original work. Despite the fact that this was an unfinished work, it was a fundamental publication that marked the origin of ichthyology as we know it today. After a long (96 pages) introduction describing previous authorities on ichthyology the second part deals with the taxonomic terminology he used, particularly regarding the concept of genus and distinguishing between species and varieties. His system set the basis for the modern systematic classification of living organisms later established by Linnaeus. In part three he went into the classification of species including detailed description of them, some of which he had dissected himself. For this Artedi is considered the father of ichthyology (Wheeler 1962, 1987, Broberg 1987).

\footnotetext{
${ }^{20} b .10$ March 1705, Anundsjö, Västernorrland, Sweden; d. 27-28 September 1735, Amsterdam, The Netherlands.
} 
Artedi separated actual fishes from cetaceans (which he called "plagiuri") based on the plane of the caudal fin. He described 7 genera and 14 species including the manatee and the "siren" as follows:

Order: Plagiuri

Physeter

Balaena major (Ray, p. 15)

Balaena macrocephala (Ray, p. 16)

Delphinus

Delphinus (Phocaena) (Art. Syn. 104)

Delphinus (Delphin) (Art. Syn. 105)

Delphinus (Orca) (Art. Syn. 106)

Balaena

Balaena vulgaris (Ray p. 6, 16)

Balaena edentula Fin-Fish (Ray p. 6, 10)

Balaena tripinnis (Ray 16)

Balenae (Balaena tripinnis) (Ray 17)

Monodon

Monoceros pisces (Will. 42, Ray 11, Charleton 168)

Catodon

Balaena minor (Ray p. 15)

Balaena major (Ray p. 17, Will. P. 41)

Trichechus

Manatus (Rondelet p. 490, Gessner p. 213, Charleton 169, Aldrovandi 7

28, Jonston 223)

Siren

Homo marinus

Artedi established the basic classification of fishes that lasted for about 200 years and separated cetaceans into a totally different order than fishes; he apparently knew that they were different, but still tradition was difficult to break and thus he included them into his ichthyological treatise. He also established the basic branching of animal groups into Class, Maniples (Families), Genera, and Species, a system that was to be closely followed by Linnaeus (Wheeler 1987, Broberg 1987). His work set the foundations for what Linnaeus would culminate as the definitely recognition of cetaceans as distinct group within mammals. 


\subsection{Carolus Linnaeus}

Linnaeus (or Linné $)^{21}$ had as a father a country person who loved plants. Linnaeus followed a medical career but was actually more interested in botany than in anything else. Linnaeus met Artedi in 1729 and their interests were complementary: Artedi, a zoologist interested mostly on fishes, and Linnaeus, interested in botany. He would later edit Artedi's book in ichthyology that was published in 1738. What Linnaeus learned from Artedi set the basis for a better classification not only of plants but also animals in general.

Even some of Linnaeus students were developing a better understanding of cetaceans as being really close to "viviparous quadrupeds." That was the case of Pehr Löfling22, one of Linnaeus' students who came very close to making major contributions to the true nature of dolphins and manatees based on his observations of these animals in South America. In his description of Amazon freshwater dolphin or boto, Löfling was clear about when writing that whales and dolphins were different from fishes: "Pisces per pulmonibus spirantibus." However, his early death and the fact that his manuscripts were never published prevented him from gaining recognition in the scientific community (Romero $e t$ al. 1997).

With all of this background, the botanist Linnaeus was ready to revolutionize biological classification and in the 10th Edition (1758) of his fundamental work Systema Naturae, he introduced the term Mammalia, and included Cete among them. For Linnaeus, mammals were united by having hair, being viviparous, and producing milk. He coined the term cetacea and separated them from fishes and grouped them with the rest of the viviparous quadrupeds based on the following characteristics: two-chamber heart, breathing by lungs, hollow ears, internal fertilization, and production of milk.

Thus, Linnaeus revolutionized the science of systematics by developing a fully natural system of classification, using consistently the binomial nomenclature, and designing species with Latinized names (genus and species). He developed a hierarchy (class, order, genus, species) as proposed by Artedi, with species defined as similar individuals bound together by reproduction, which also set the basis of the biological species concept. The use of telegraphic speech-like (very short sentences) diagnosis for species descriptions and the standardization of synonymies (same species with different names) in order to reach a taxonomic consensus made his classification even more useful since from now on one could find clarity on what a particular species was tracing its description to other authors. He also doubled the number of species described by Ray. Thus, despite the fact that he was not a zoologist per se nor was involved in dissection of animals, he was far from a compiler in that he applied critical thinking to the way he ordered nature.

\footnotetext{
21 b. 23 May 1707, Stenbrohult, Småland, Sweden; $d$. 10 January 1778, Uppsala, Sweden. ${ }^{22} b .1729$, Valbo, Sweden; $d$. 22 February 1756, Guayana, Venezuela.
} 
This progress is even more remarkable when considering that Linnaeus was far from an evolutionist. For him species were fixed except for small variations due to climatic/local conditions. Yet, Linnaeus was, without question, the founder of systematics and the one who laid the foundations for the naturalists to become specialists and, therefore, opened the door for the first group of marine mammal specialists, now that these creatures were not longer considered "fishes." It was not until Linnaeus that the science of taxonomy made the strides that have lead us to where we are today in our understanding of the natural world. Linnaeus understood biological principles and placed animals in groups based on homologies rather than using environment to drive classification, and this was what allowed him to recognized cetaceans as a distinct group within mammals.

\section{Conclusion}

Persuing at the information provided above there are a number of discernable patterns. One is the preponderance of pre-Linnean researchers interested in marine mammals who had a medical background of some sort. That is not surprising because medicine was the closest thing to science as a career existed until the eighteenth century. Also, being interested in medicine created more opportunities to dissect animals and, therefore, understanding of their internal anatomy that was particularly crucial in establishing the homology between cetaceans and the "viviparous quadrupeds." Yet, this positive influence was marred by the proliferation of encyclopedists who, for the most part, were uncritical compilers of other authors' information. However, the major impediment to any attempts to develop a natural classification for cetaceans was the insistence on classifying them by virtue of the environment in which they live, something that even diverted the thoughts of keen observers such as Ray and Artedi, despite of abundant evidence to the contrary having been collected since Aristotle.

Finally, we should not overlook the role played by intellectual inertia in the development of science. As Horder (1998) clearly demonstrated, scientists need to know the history of their field to avoid errors of the past, something that has also been argued for specific fields of biology (see Romero 2009, Chapter 1).

\section{Author details}

Aldemaro Romero

College of Arts and Sciences, Southern Illinois University Edwardsville, Peck Hall, Edwardsville, IL, USA

\section{Acknowledgement}

I thank Dr. Matthew Cashen for his advice interpreting Aristotle's writings and to Dr. Carl Springer for similar help with Pliny's work. 


\section{References}

Aldrovandi, U. 1613. U. Aldrovandi ... de Piscibus libri V et de Cetis lib. Uncus. Bononiae, $732 \mathrm{pp}$.

Alves, W.L. 2010. Ulisse Aldrovandi's Opera Omnia: collecting natural wonders. Thesis: Departmental Honors in Art History, Wheaton College, Norton, MA. 179 pp.

Artedi, P. 1738. Ichthyologia sive opera omnia piscibus scilicet: Bibliotheca ichthyologica. Philosophia ichthyologica. Genera piscium. Synonymia specierum. Descriptiones specierum. Omnia in hoc genere perfectiora, quam antea ulla. Posthuma vindicavit, recognovit, coaptavit $\mathcal{E}$ edidit Carolus Linnaeus, Med. Doct. \& Ac. Imper. N.C. Wishoff, Leiden.

Barnes, J. 1995. Life and work, pp. 1-26, In: J. Barnes (Ed.). The Cambridge Companion to Aristotle. Cambridge: Cambridge University Press.

Bay, J.C. 1916. Gesner, the father of bibliography. Papers of the Bibliographical Society of America 10:53-88.

Belon, P. 1551. L'histoire naturelle des estranges poissons marins : avec la vraie peincture \& description du daulphin, \& de plusieurs autres de son espece. De l'imprimerie de Regnaud Chaudiere. Paris.

Belon, P. 1551. La nature et la diversité des poisons. Avec leurs pourtraicts representez au plus près naturel. Ch. Estienne: Paris.

Booth, E. 2005. 'A subtle and mysterious machine'. The medical world of Walter Charleton (1619-1707). Dordrecht: Springer.

Broberg, G. 1987. Petrus Artedi in his Swedish context. Proc. V Congr. Europ. Ichthyol., Stockholm 1985, pp. 11-15.

Charleton, W. 1668. Onomasticon zoicon plerorumque Animalium Differentias et Nomina Propria pluribus Linguis exponens. Cui accedunt Mantissa Anatomica et quaedam de Variis Fossilium Generibus. Jacobum Allestry, London. 363 pp.

Charleton, W. 1677. Exercitationes de Differentiis \& Nominibus Animalium. Oxford. 343 pp.

Collins, S. 1685. A Systeme of Anatomy treating of the body of man, beasts, birds, fish, insects and plants. Illustrated with many schemes, consisting of variety of elegant figures, drawn from the life, and engraven in seventy four Folio copper plates and after every part of man's body hath been anatomically described, its diseases, cases and cures are concisely exhibited. London, 2 vol.

Delaunay, P. 1926. Pierre Belon naturaliste. Le Mans: Imprimerie Mannoyer.

Dulieu, L. 1966. Guillaume Rondelet. Clio Medica. 1:89-111.

Ellwood, C.A. 1938. A history of social philosophy. New York: Prentice Hall.

Gudger, E.W. 1934. The five great naturalists of the sixteenth century: Belon, Rondelet, Salviani, Gesner, and Aldrovandi: a chapter in the history of ichthyology. Isis 22:21-40.

Fischer, H. 1966. Conrad Gessner (1516-1565) as bibliographer and encyclopedist. The Library 21:269-281.

Gessner, C. 1558. Historiae Animalium. Liber IIII qui est de Piscium \& Aquatilium natura... Tiguri 
Glardon, P. 2011. L'Histoire naturelle au XVIe Siècle. Genève: Libraire Droz S.A.

Gmelig-Nijboer, C.A. 1977. Conrad Gessner's “Historia Animalium" an inventory of Renaissance Zoology. Utrecht: Communicationes Biohistoricae Ultrajectinae.

Horder, T. J. 1998. Why do scientists need to be historians? Quarterly Review of Biology 73:175-187.

Impey, O. \& A. MacGregor. 1985. The origins of museums. The cabinet of curiosities in sixteenthand seventeenth-Century Europe. Oxford: Clarendon Press.

Jonston, J. 1657. Historiae naturalis de piscibus et cetis libri $V$, cum aeneis figuris, Johannes Jonstonus,... concinnavit. J. J. Schipperi, Amsterdam. 306 pp.

Kargon, R. 1964. Walter Charleton, Robert Boyle, and the acceptance of Epicurean Atomism in England. Isis 55:184-191.

Keller, A.G. 1975. Rondelet, Guillaume, pp. 527-528, In: C.C. Gillispie (Ed.). Dictionary of Scientific Biography, Vol. 9. New York: Scribner's Sons.

Kruger, L. 2003. Edward Tyson's 1680 account of the 'porpess' brain and its place in the history of comparative neurology. Journal of the History of the Neurosciences 12:339-349.

Kruger, L. 2004. An early illustrated comparative anatomy of the brain: Samuel Collins' A Systeme of Anatomy (1685) and the emergence of comparative neurology in 17th century England. Journal of the History of the Neurosciences 13:195-217.

Kusukawa, S. 2000. The Historia Piscium (1686). Notes Rec. Royal Society London 54:179-197.

Kusukawa, S. 2010. The sources of Gessner's pictures for the Historia animalium. Annals of Science 67:303-328.

Leu, U.B.; R. Keller \& S. Weidmann. 2008. Conrad Gessner's private library. Leiden: Brill.

Leitner, H. 1927. Zoologische terminologie beim älteren. Hildesheim: Verlag.

Lewis, E. 2001. Walter Charleton and early Modern Eclecticism. Journal of the History of Ideas 62:651-664.

Linnæus, C. 1758. Systema naturæ per regna tria naturæ, secundum classes, ordines, genera, species, cum characteribus, differentiis, synonymis, locis. Tomus I. Editio decima, reformata. - pp. [1-4], 1-824. Holmiæ. (Salvius).

Locher, A. 1984. The structure of Pliny the Elder's Natural History, pp. 20-29, In: Science in the Early Roman Empire: Pliny the Elder, his sources and influence (R. French and F. Greenaway, Eds.). London: Croom Helm.

Miller, G.L. 2008. Beasts of the New Jerusalem: John Jonston's natural history and the launching of millenarian pedagogy in the seventeenth century. History of Science 46:203-243.

Montagu, A. 1943. Edward Tyson, M. D., F. R. S., 1650-1708, and the rise of human and comparative anatomy in England; a study in the history of science. Philadelphia: The American Philosophical Society.

Moseley, A. 2010. Aristotle. London: Continuum International Publishing Group.

Murphy, T. 2004. Pliny the Elder's Natural History: The Empire in the Encyclopedia. Oxford: Oxford University Press.

Naas, V. 2002. Le projet encyclopédique de Pline L'Ancien. Rome: Ecole Française de Rome. 
Nutton, V. 1985. Illustrations from the Welcome Institute Library. Medical History 29:93-97. Oppenheimer, J.M. 1936. Guillaume Rondelet. Bulletin of the Institute of the History of Medicine. 4: 817-834.

Raven, C.E. 1950. John Ray naturalist. His life and works. Cambridge: University Press.

Ray, J. 1671. An account of the dissection of a porpess, promised Numb. 74, made, and communicated in a Letter of Sept. 12, 1671, by the learned M. John Ray., having therein observ'd some things omitted by Rondeletius. Philosophical Transactions (Royal Society) 6:2274-2279.

Ray, J. 1686. Franciscus Willughbei...De historia piscium libri quatuor. Oxonii, 343+30 pp.

Ray, J. 1713. Synopsis methodica avium \& piscium; opus posthumum...Londini, $166 \mathrm{pp}$.

Reynolds, J. 1986. The Elder Pliny and his times, pp. 1-10, In: Science in the Early Roman Empire: Pliny the Elder, his sources and influence (R. French and F. Greenaway, Eds.). London: Croom Helm.

Rolleston, H. 1940. Walter Charleton, D.M., F.R.C.P., F.R.S. Bulletin of the History of Medicine 8:403-406.

Romero, A. 2009. Cave Biology: Life in Darkness. Cambridge: Cambridge University Press.

Romero, A., A.I. Agudo and S.J. Blondell. 1997. The scientific discovery of the Amazon river dolphin Inia geoffrensis. Marine Mammal Science 13(3):419-426.

Rondelet, G. 1554-1555. Libri de piscibus marinis...Universae aquatilium historiae pars altera...Lugduni, 583 pp.

Rondelet, G. 1558. La Premiere Partie de l'Histoire entiere des Poissons ... Lyon, France. 599 pp.

Sharpe, L. 1973. Walter Charleton's Early Life, 1620-1659, and Relationship to Natural Philosophy in Mid-Seventeenth Century England. Annals of Science 30:311-340.

Simpson, G. G., 1945. The principles of classification and a classification of mammals. Bulletin of the American Museum of Natural History 85: 163 - 216.

Tugnoli Pattaro, S. 1994. Scienziati pionieri all'Universita di Bologna: il caso Aldrovandi. Forum Italicum 8:1130124.

Tyson, E. 1680. Phocaena, or, The anatomy of a porpess dissected at Gresham Colledge, with a preliminary discourse concerning anatomy and natural history of animals. Benj. Tooke, London. 48 pp.

Wellisch, H.H. 1984. Conrad Gessner. A Bio-Bibliography. Zug: IDC.

Wheeler, A.C. 1962. The life and work of Peter Artedi, (pp. vii-xxi) In: Peter Artedi Ichthyologia. New York: Wheldon \& Wesley.

Wheeler, A.C. 1987. Peter Artedi, founder of modern ichthyology. Porc. Congr. Europ. Ichthyology., Stockholm 1985. , pp. 3-10.

Wong, M. 1970. Belon, Pierre. Pp. 595-596, In: C.C. Gillispie (Ed.). Dictionary of Scientific Biography, Vol. 1. 
Wotton, E. 1552. De differentiis animalium libri decem ... cum amplissimus indicibus, in quibus primùm authorum nomina, unde quaequae desumpta sunt, singulis capitibus sunt notata \& designata: deinde omnium animalium nomenclaturae, itémque singulae eorum partes recensentur, tam Graecè, quàm Latinè. Paris. 